\title{
Soil water effects on growth and nutrition in upland pastures
}

\author{
A.E.S. MACKLON, L.A. MACKIE-DAWSON, C.A. SHAND AND A. SIM
}

The authors are research scientists in Plants Division, Macaulay Land Use Research Institute, Craigiebuckler, Aberdeen $A B 92 Q J$, Scotland, U.K.

\begin{abstract}
Normally the oceanic climate of Scotland maintains soils at low levels of soil water deficit. Field data for such a year are presented and compared with those for an unusually dry year, with the objective of assessing to what degree dry spells might limit herbage production in upland pastures. One meter square plots were sampled on selected dates on reseeded pastures growing on each of 3 cambisols, each derived from different parent materials. The swards were unfertilized and maintained at nominal heights of $2,4,7$, and $10 \mathrm{~cm}$ by cutting every 2 or 3 weeks to manipulate growth and demand for $P$ and $N$. Overall yield was 25 to $\mathbf{5 0 \%}$ lower in the dry year compared with an average year. Peaks and troughs in growth rates, measured as yield at each cutting, and in $\mathbf{P}$ and $\mathbf{N}$ content, corresponded to changes in soil water deficit in the top meter of soil. The linear correlation coefficient between soil water deficit and growth rate was $-0.894(P=$ $0.001)$. Although there was some variation in volumetric water content between soils, soil water deficits were similar in all the cambisols. Yields and nutrient contents were generally similar for herbage harvested from the $\mathbf{2}$ soils having basic parent material (one a eutric and one a dystric cambisol) and lower on the dystric cambisol derived from schists. The effects of water content largely over-rode cutting treatments, demonstrating that dry spells occasionally occuring in the oceanic climate of Scotland can significantly affect grassland production.
\end{abstract}

Key Words: soil water content, phosphorus, nitrogen, acid soils, cutting height

Investigations on the effect of grazing, simulated by herbage cutting regimes, on a range of herbage characteristics have been reported by a number of workers. Barthram et al. (1992) and Grant and Barthram (1991) used the technique to manipulate clover composition of the sward, whilst Käding (1990) related cutting height to species composition and yield. In some work, the principal goal of cutting regime experiments was to relate yield to the nutritional quality of the herbage in terms of crude protein content and digestibility (Mayland et al. 1992, Reid 1962 and 1968, Willms and Beauchemin 1991). Many studies involved the interaction of fertilizers (e.g. Frame 1973, Holliday and

The research was funded by the Scottish Office Agriculture and Fisheries Department. Meteorological data is reproduced with the permission of the Controller of Her Majesty's Stationery Office. The authors wish to thank S.M.

Pratt for neutron probe readings.

Manuscript accepted 22 July 1995.
Wilman 1965, Orr and Laidlaw 1978), whereas some work was concerned with the effect of cutting regime on yield (Reid 1959, Willms 1991).

In this paper, the effects of a range of cutting regimes on yield of mixed grassland are reported and comparisons are made between data for an average precipitation year and an unusually dry year. Cutting treatments were designed to manipulate herbage demand on soil water, and also soil $\mathrm{P}$ and $\mathrm{N}$ resources (Macklon et al. 1994). Experimental sites were established on 3 cultivated brown forest soils in the Upper Don basin in N.E. Scotland. No fertilizer additions were made during the study, the emphasis being on soil $\mathrm{P}$ and $\mathrm{N}$ supply and growth in an extensively managed grassland system. This study complements and extends that of Jones and Tinsley (1980), who also worked in the higher reaches of the Don Valley. The objective of the work was to investigate the significance of soil water in determining growth rates and $P$ and $N$ levels in upland pastures which rarely experience soil water stress. Other soil and plant studies on the same experimental sites are reported in related papers (Shand et al. 1994a,b, Macklon et al. 1994).

\section{Materials and Methods}

Site Characteristics and Herbage Components

Sites characterized in Table 1, on cambisols in Glenbuchat, were fenced off in June 1988. Each enclosure was $10 \mathrm{~m}^{2}$ within which was marked out a block of 24 plots, each a meter square, the whole area surrounded by a margin at least a meter wide. Until fenced, the Foudland site had been fertilized with $250 \mathrm{~kg}$ $\mathrm{ha}^{-1}$ 25:5:5 NPK annually. Insch and Tarves were not fertilized in the year preceding fencing. In 1988 at Foudland and Insch sites, the pastures were 10 years old and at Tarves 7 years old.

Depths of horizons $\mathrm{A}$ and $\mathrm{B}, \mathrm{pH}$ and organic matter content (\% loss on ignition) are given for each site (Table 2). All pasture sites were classified as Lolio-cynosuretum associations (Robertson 1984). Sward components are given in Table 3. Ephemeral species made up only a small proportion of the sward and cutting, followed by raking, minimised the build up of scenescent material.

\section{Herbage Treatments}

Cutting regimes were imposed to a $2,4,7$, or $10-\mathrm{cm}$ stubble on 4 plots selected randomly at each site. Cutting started after sites were enclosed in 1988 and from early May during 1989. No graz- 
Table 1. Site locations and soil characteristics for plots from which herbage was harvested in Glenbuchat.

\begin{tabular}{|c|c|c|c|c|c|c|c|}
\hline \multicolumn{2}{|c|}{ Soil type } & \multirow{2}{*}{$\begin{array}{l}\text { Parent } \\
\text { material }\end{array}$} & \multirow{2}{*}{$\begin{array}{l}\text { Soil } \\
\text { association }\end{array}$} & \multirow{2}{*}{$\begin{array}{l}\text { National grid } \\
\text { reference }\end{array}$} & \multirow[b]{2}{*}{ Elevation } & \multirow[b]{2}{*}{ Slope } & \multirow[b]{2}{*}{ Aspect } \\
\hline $\mathrm{UK}^{1}$ & $\mathrm{US}^{2}$ & & & & & & \\
\hline $\begin{array}{l}\text { Eutric } \\
\text { cambisol }\end{array}$ & $\begin{array}{l}\text { Typic } \\
\text { cryochrept }\end{array}$ & $\begin{array}{l}\text { Basic rocks } \\
\text { and derived } \\
\text { drifts }\end{array}$ & Inschr $^{3}$ & NJ 346195 & $\begin{array}{l}\text { (m) } \\
411\end{array}$ & $\begin{array}{c}\text { (degrees) } \\
8\end{array}$ & Sw \\
\hline $\begin{array}{l}\text { Dystric } \\
\text { cambisol }\end{array}$ & $\begin{array}{l}\text { Dystric } \\
\text { cryochrept }\end{array}$ & $\begin{array}{l}\text { Intermediate } \\
\text { and basic } \\
\text { gneiss and } \\
\text { derived } \\
\text { drifts from } \\
\text { acidic and } \\
\text { basic rocks }\end{array}$ & Tarves $^{3}$ & NJ 348184 & 377 & 15 & sw \\
\hline $\begin{array}{l}\text { Dystric } \\
\text { cambisol }\end{array}$ & $\begin{array}{l}\text { Dystric } \\
\text { cryochrept }\end{array}$ & $\begin{array}{l}\text { Fine-grained } \\
\text { schists and } \\
\text { derived } \\
\text { drifts }\end{array}$ & Foudland $^{3}$ & NJ 341195 & 396 & 10 & $\mathrm{E}$ \\
\hline
\end{tabular}

Soil terminology follows that adopted by the UN Food and Agriculture Organisation, and European usage.

${ }^{2}$ Based on Ragg and Clayden (1973).

${ }^{3}$ Soil Survey of Scotland (1969).

ing had occurred since 1987. Cutting heights were estimated by the use of quadrats with frames fitted to the appropriate height for each cutting treatment. The quadrats $(50 \mathrm{~cm} \times 50 \mathrm{~cm})$ were placed centrally in each plot, while herbage was cut and harvested. The whole $1 \mathrm{~m}^{2}$ of each plot was then cut to the appropriate treatment height and the cuttings discarded. Harvested herbage was oven dried at $70^{\circ} \mathrm{C}$ for 48 hours, weighed, milled using a 0.4 $\mathrm{mm}$ screen and prepared for analysis.

\section{Chemical Analysis}

For $P$ analysis, herbage subsamples $(0.25 \mathrm{~g})$ from well mixed millings of each sample, were ashed at $500^{\circ} \mathrm{C}$ overnight. The ash was dampened with distilled water before addition of $4 \mathrm{ml}$ of $6 \mathrm{M}$ redistilled $\mathrm{HCl}$. After evaporating to dryness and rewetting with concentrated $\mathrm{HCl}$ several times, extracts were taken up in 340 $\mathrm{mM} \mathrm{HCl}$, and after filtering, made to a suitable volume. Total phosphorus was determined by ICP spectrometry. Total nitrogen was estimated on subsamples of the milled herbage using a $\mathrm{C} / \mathrm{H} / \mathrm{N}$ analyzer (Carlo Erba Instrumentazion, Milan, Italy). To determine $\mathrm{pH}$ (Table 2), $10 \mathrm{~g}$ of field moist soil were added to 20 $\mathrm{ml}$ distilled water and shaken overnight before measurements.

\section{Meteorology}

Rainfall was measured by automatic funnel gauges (Fig. 1). Air temperatures were not measured at Glenbuchat, but published

Table 2. Soil profile details for plots from which herbage was harvested in Glenbuchat.

\begin{tabular}{lcccc}
\hline Site & Horizon & $\begin{array}{c}\text { Depth of } \\
\text { horizon }\end{array}$ & $\mathrm{pH}$ & loss on ignition $^{\mathrm{a}}$ \\
\hline \multirow{4}{*}{ Insch } & $\mathrm{A}$ & $(\mathrm{cm})$ & & $(\%)$ \\
& $\mathrm{B}$ & $0-26$ & 5.62 & 13.6 \\
Tarves & $\mathrm{A}$ & $0-30$ & 5.81 & 6.1 \\
& $\mathrm{~B}$ & $30-60$ & 5.77 & 11.6 \\
Foudland & $\mathrm{A}$ & $0-23$ & 5.79 & 6.9 \\
& $\mathrm{~B}$ & $23-52$ & 5.65 & 11.5 \\
& & & & 7.3 \\
\hline
\end{tabular}

${ }^{a} \mathrm{An}$ index of organic matter content values for Glenlivet ( $9 \mathrm{~km} \mathrm{NW}$ ) and Insch (23 km ENE, and in the same prevailing airstream, were adjusted for altitude $\left(0.6^{\circ}\right.$ per $100 \mathrm{~m}$, Meteorological Office Monthly Weather Reports) and extrapolated to Glenbuchat. Air temperatures were measured at $1.5 \mathrm{~m}$ above ground level.

\section{Soil Water}

Volumetric soil water content was measured in the field by a neutron probe technique (McGowan and Williams 1980). Three replicate permanent neutron moisture meter access tubes were installed to approximately $1 \mathrm{~m}$ depth, as described by Howse (1981), at each site. Volumetric water content down the profile was measured with a Wallingford moisture meter at monthly intervals in 1988 and 1989. Neutron probe data were converted to water content values from a calibration curve established using a Wallingford probe (Bell 1976). Soil water deficits (for monthly intervals) were calculated by subtracting profile water content from field capacity values determined using a pressure sensor (Thies Clima, Göttingen, Germany) to measure the pressure inside septum tensiometers (Hendrickx 1990). Six tensiometers were installed on the plots maintained at 4-cm sward height, at each site at 3 depths ( $\times 2$ replicates).

\section{Statistical Methods}

For yield and $\mathrm{P}$ and $\mathrm{N}$ content, variability in the data is shown in the figures by bars indicating the standard error of the mean

Table 3. Species composition of mixed grassland sites; June 1989.

\begin{tabular}{lccc}
\hline \hline Species & \multicolumn{3}{c}{ Sites } \\
\cline { 2 - 4 } & Insch & Tarves & Foudland \\
\hline & - & $(\%)$ & 30 \\
Cynosurus cristatus L. & 45 & 20 & 20 \\
Lolium perenne L. & 5 & 5 & 10 \\
Arrhenatherum elatius L. & - & 5 & -10 \\
Phleum pratense L. & - & 5 & 15 \\
Dactylis glomerata L. & 35 & 20 & 10 \\
Trifolium repens L. & 5 & 10 & 5 \\
Bellis perennis L. & 5 & 5 & \\
Ranunculus repens L. & 5 & &
\end{tabular}



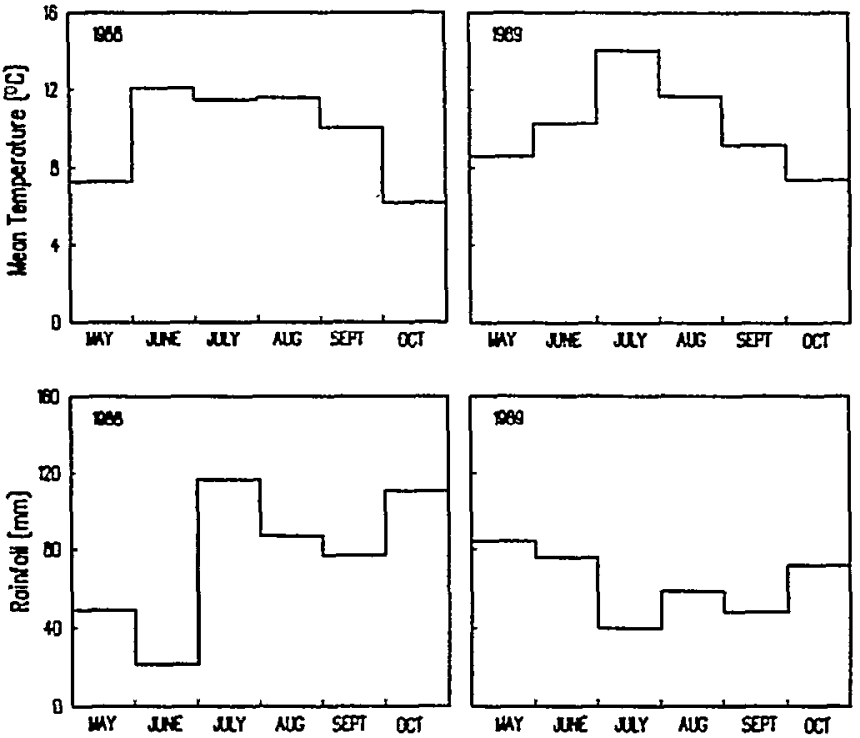

Fig. 1. Monthly rainfall and mean air temperature values during the 1988 and 1989 growing seasons. Mean air temperatures are based on Meteorological Office data (by permission).

$(n=4)$. Significant differences in soil water data were determined using analysis of variance $(n=10)$. When the mean effect of the treatment was significant, least significant differences were calculated using the t-test. A linear correlation between soil water deficit and growth (yield, $\mathrm{kg} \mathrm{ha}^{-1} \mathrm{day}^{-1}$ ) in the period following each soil water deficit measurement, for plots maintained at $4 \mathrm{~cm}$ height, was calculated on the basis of 9 values (taken from all sites during the growing season).

\section{Results and Discussion}

\section{Soil Water}

In 1989 rainfall was much lower than the average experienced in 1988 (Fig. 1). It seemed likely that water availability could become the limiting factor for growth after the spring flush, as demonstrated for ryegrass/clover swards by Appadurai and Holmes (1964), using a range of irrigation rates. This view was confirmed by a significant correlation between yield and soil water deficit across the 3 experimental sites in $1989(r=-0.894$, $P=0.001$ ). No significant correlation between yield and soil water deficit was found in 1988 for which measurements were made only in August and October (Fig. 2).

Soil water deficit data (Fig. 2) revealed an increasing deficit during May, as sward growth accelerated, and then a reduction before the secondary peak in growth related to a brief rainfall event at the end of June. From this point on, soil water deficit continued to increase much beyond the modest level of August the previous year.

In terms of water content, the Foudland soil was wetter than the other 2 sites for most of the year (Fig. 3). The 26 July date was chosen to represent profile differences at one of the driest times. The 3 depths $0-15,15-25$, and $25-35 \mathrm{~cm}$ were significantly wetter at the Foudland site than at the other 2 sites at this date $(P<$ 0.05 ). The total profile to $95 \mathrm{~cm}$ depth was also wetter at the Foudland site than the other 2 sites at this date $(P<0.05)$ and for

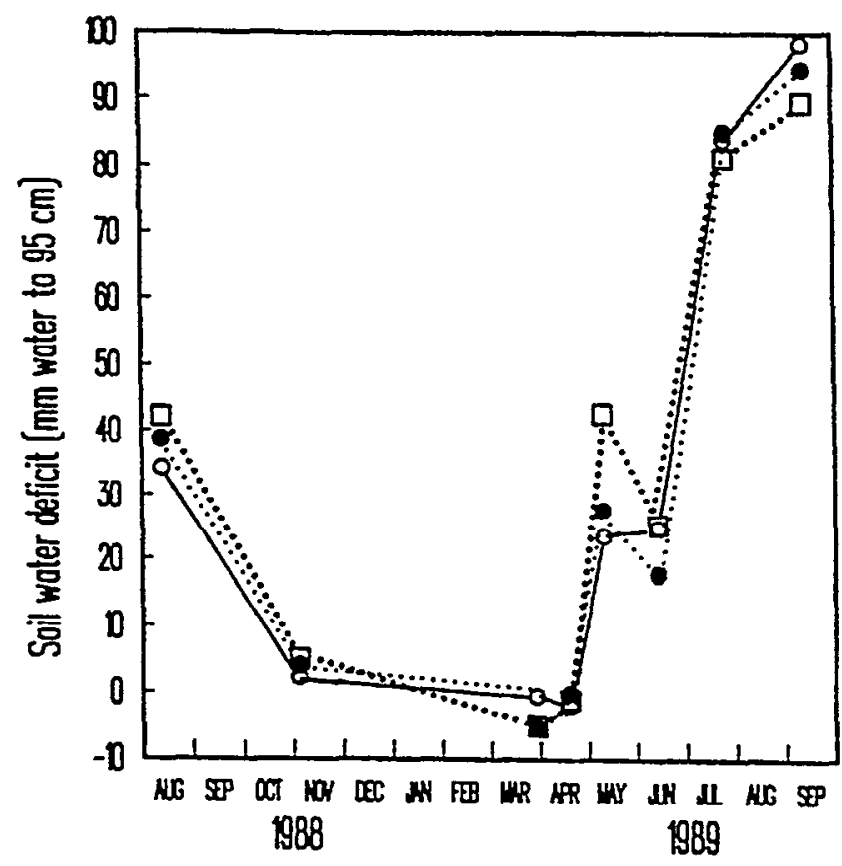

Fig. 2. Soil water deficit (mm water to 95-cm depth) at Insch $-0-$, Tarves $\cdots \cdot \cdots \cdot . .$. , and Foudland $\cdots \square \cdots$ sites throughout the study period. Values are means $(n=3)$ and no significant differences between sites were found at any date.

most of the growing season (data not shown). However, no significant difference in soil water deficit occurred between these sites at any date (Fig. 2).

\section{Herbage Growth}

Enclosure of the ungrazed experimental sites was not completed until June 1988. Therefore the first cut and harvest represented growth for the first entire month of the growing season (Fig. 4).

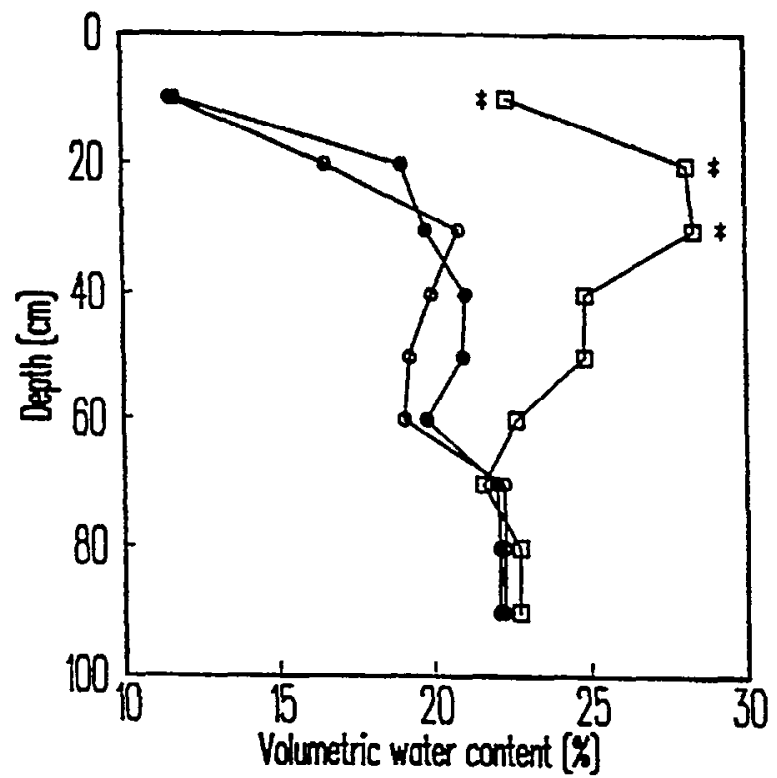

Fig. 3. Volumetric water content (\%) down the profile on $26 \mathrm{July}$ 1989 at Insch $(0)$, Tarves $(\bullet)$, and Foudland (D) sites. Values are means $(n=3)$ and * denotes where values were significantly different at $P<0.05$. 

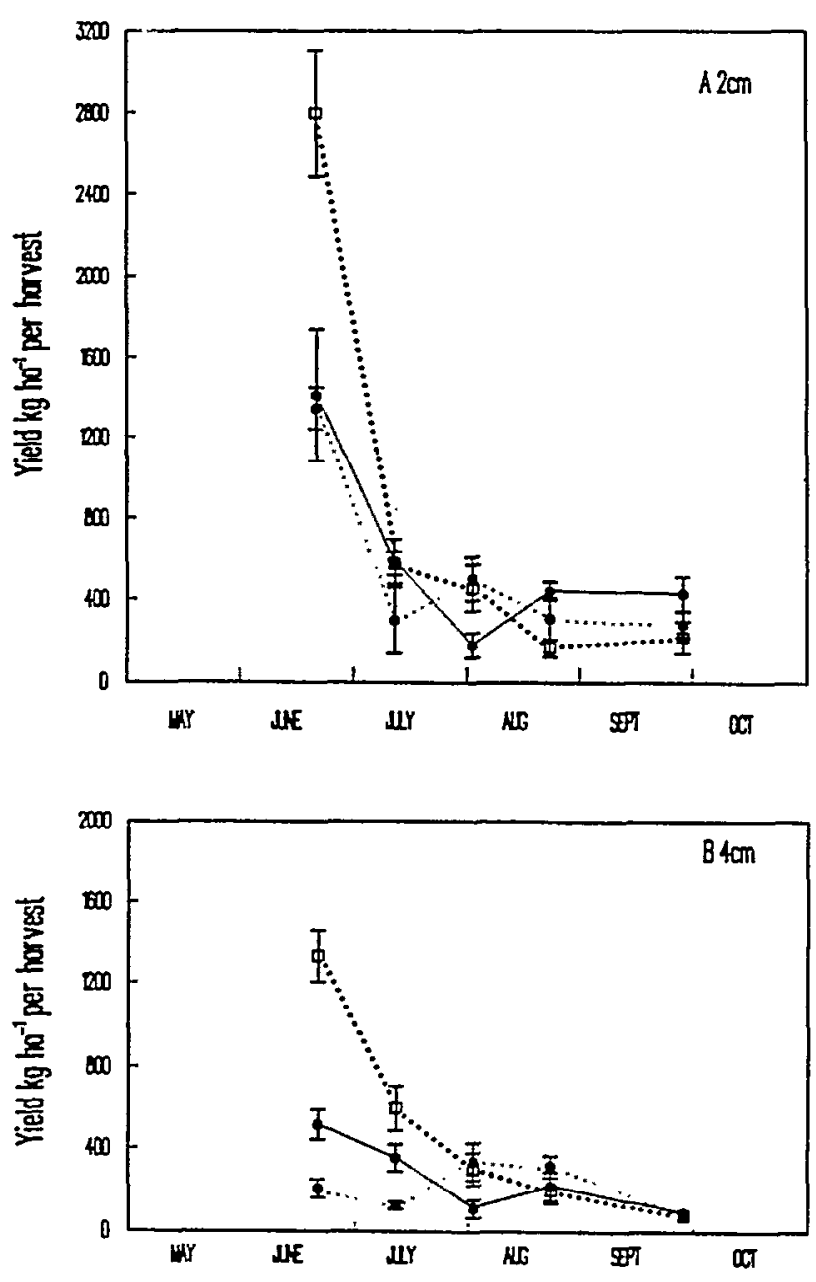

Fig. 4. Yields of herbage harvested at each cut to nominal heights (A) $2 \mathrm{~cm}$ and $(B) 4 \mathrm{~cm}$, in 1988. Insch - - , Tarves $\cdots . . . .$. , Foudland $\cdots \square$.... Bars show standard errors of means $(n=d)$.

Although rainfall was low in June, growth was sustained by soil water reserves accumulated during the previous winter (Fig. 2), and by the high temperature (Fig. 1). The high yield on the Foudland site in the first month of growth was attributed to residual fertilizer applied in 1987. After the spring flush (Fig. 4), yield gradually fell at Foudland, and showed small peaks in July and August at the other 2 sites, at both nominal heights ( 2 and $4 \mathrm{~cm}$ ).

In 1989 , cutting started when nominal height was exceeded in May. The taller the sward level, the later the first cut became due (Fig. 5). With all treatments a general flush of growth occurred to varying degrees in June, followed by a lower growth rate at the end of June and in early July. This was followed by a second smaller flush later in July. For 2-cm swards, the main flush of growth occurred in July (Tarves and Foudland). For Insch, there was 1 main flush in June (Fig. 5). This pattern of growth, correlated with soil water deficit, can be compared with the 1988 data, which show steadier reductions in yield when rainfall was near average for Scotland's oceanic climate.

The difference in water deficits between 1988 and 1989 is reflected by total yields in both seasons (Table 4). These values
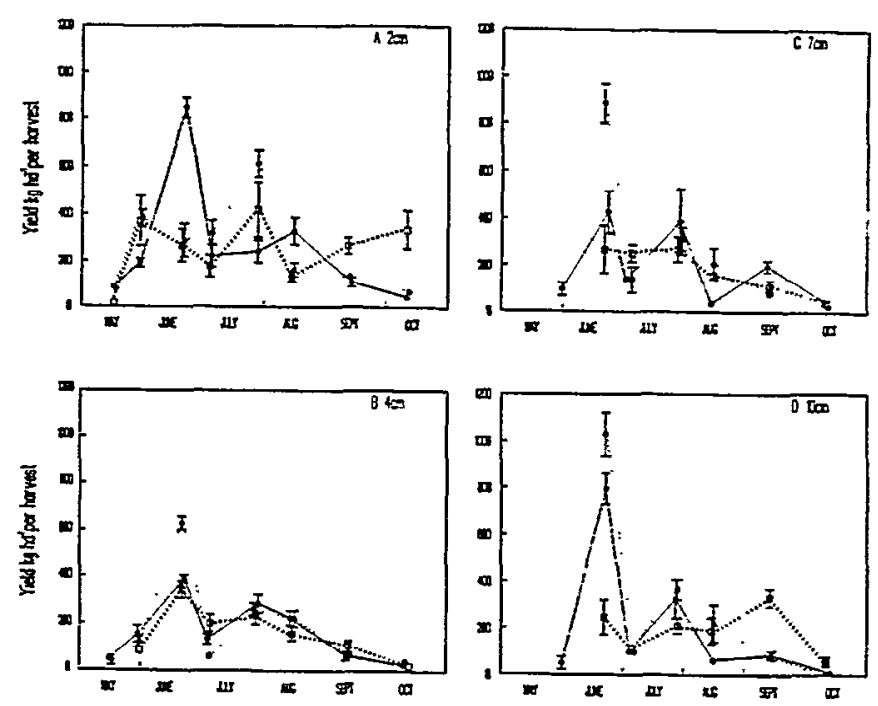

Fig. 5. Yields of herbage harvested at each cut to nominal heights (A) $2 \mathrm{~cm}$, (B) $4 \mathrm{~cm}$, (C) $7 \mathrm{~cm}$, and (D) $10 \mathrm{~cm}$, in 1989. Insch - - Tarves …・..., Foudland $\cdots \square \cdots$. Bars show standard errors of means $(n=4)$.

include a final cut to a 2-cm stubble from the 4,7, or 10-cm stubble plots to calculate yields for each treatment on the same basis. Even on the sites without the possibility of a residual fertilizer effect (Tarves and Insch) yields were 22 to $33 \%$ lower in the dry year compared with the average. In 1989 , yields tended to be lower when swards were cut to a 4 -cm stubble compared with 2$\mathrm{cm}$, and higher with 7 and 10-cm stubble heights (Table 4).

In 1988, P content increased slightly but steadily with no marked changes in growth rate to upset the trend. Nitrogen content increased through the growing season, but declined after August (Fig. 6). This compared with a steadily falling trend in 1989, interrupted by short-lived increases related to growth peaks. Though generally lower than in $1988 \mathrm{P}$ and $\mathrm{N}$ content of herbage, on a mg per unit dry weight basis, tended to increase during and immediately following periods of rapid growth both in spring and summer of 1989 , after which nutrient content declined as observed by Mayland et al. (1992) for Agropyron. However, nutrient content in our $10 \mathrm{~cm}$ treatments increased at the end of the growing season (Figs. 7 and 8). The cause and effect of this

Table 4. Total annual yield (dry weight) from plots maintained at $2 \mathrm{~cm}$ and $4 \mathrm{~cm}$ sward heights in 1988, and at 2, 4,7 and $10 \mathrm{~cm}$ heights in 1989.

\begin{tabular}{|c|c|c|c|c|}
\hline \multirow{2}{*}{\multicolumn{2}{|c|}{$\begin{array}{l}\text { Year and Sward } \\
\text { hcight }\end{array}$}} & \multicolumn{3}{|c|}{ Site } \\
\hline & & Tarves & Insch & Foudland \\
\hline & & \multicolumn{3}{|c|}{$\ldots \ldots \ldots$} \\
\hline 1988 & $2 \mathrm{~cm}$ & $2,740 \pm 360$ & $3,050 \pm 320$ & $4,220+520$ \\
\hline 1989 & $2 \mathrm{~cm}$ & $2,050 \pm 140$ & $2,080 \pm 130$ & $2,000 \pm 200$ \\
\hline 1988 & $4 \mathrm{~cm}$ & $2,260 \pm 230$ & $2,550 \pm 180$ & $3,610 \pm 240$ \\
\hline 1989 & $4 \mathrm{~cm}$ & $1,660 \pm 80$ & $1,980 \pm 170$ & $2,490 \pm 70$ \\
\hline 1989 & $7 \mathrm{~cm}$ & $3,340 \pm 260$ & $3,520 \pm 450$ & $3,030 \pm 210$ \\
\hline 1989 & $10 \mathrm{~cm}$ & $3,850 \pm 250$ & $2,620 \pm 250$ & $4,420 \pm 300$ \\
\hline
\end{tabular}

Immediately after the last cut to nominal height, all plots were cut to $2 \mathrm{~cm}$ and uhis material is included in the 4,7 , and $10-\mathrm{cm}$ totals. 

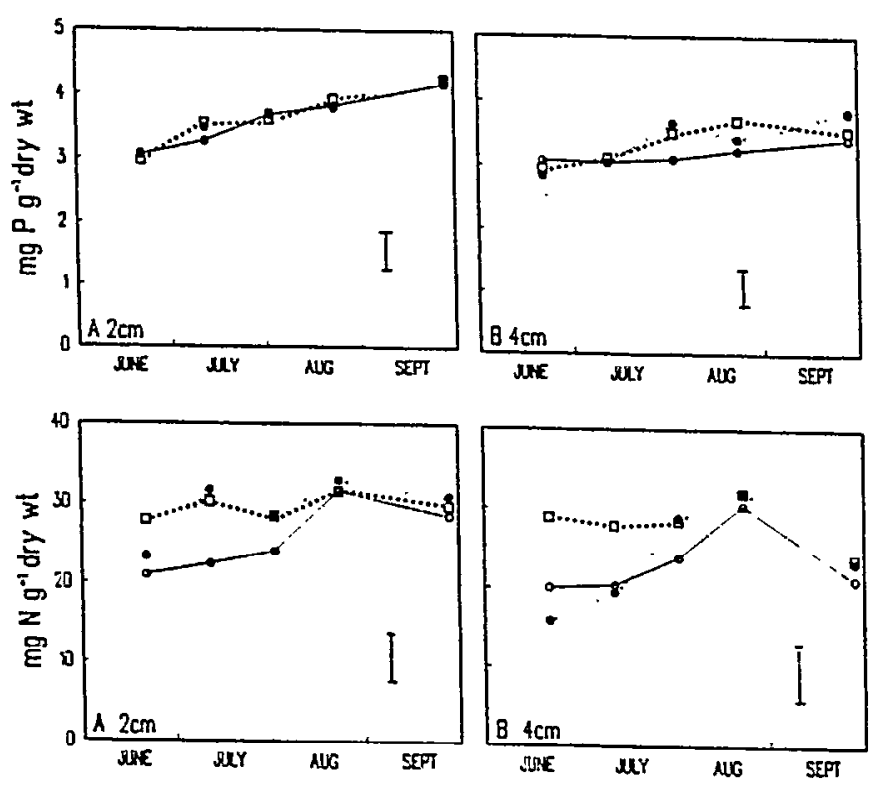

Fig. 6. Contents of $P$ (upper) and $N$ (lower) per unit dry weight in herbage harvested at each cut to nominal heights (A) $2 \mathrm{~cm}$ and (B) $4 \mathrm{~cm}$, in 1988. Insch - $0-$, Tarves ........, Foudland $\ldots . \square \ldots$. All standard errors equal to or less than vertical bar $(n=4)$.

relationship is not certain. Greater mineralisation of these nutrients when soils were wetter (Ahmed 1976) may have led to rates of nutrient uptake greater than were needed for immediate growth. This resource may then have been utilized in further growth when mineralisation was suppressed during periods of lower water content, reducing plant content of $P$ and $N$ on a unit dry weight basis.
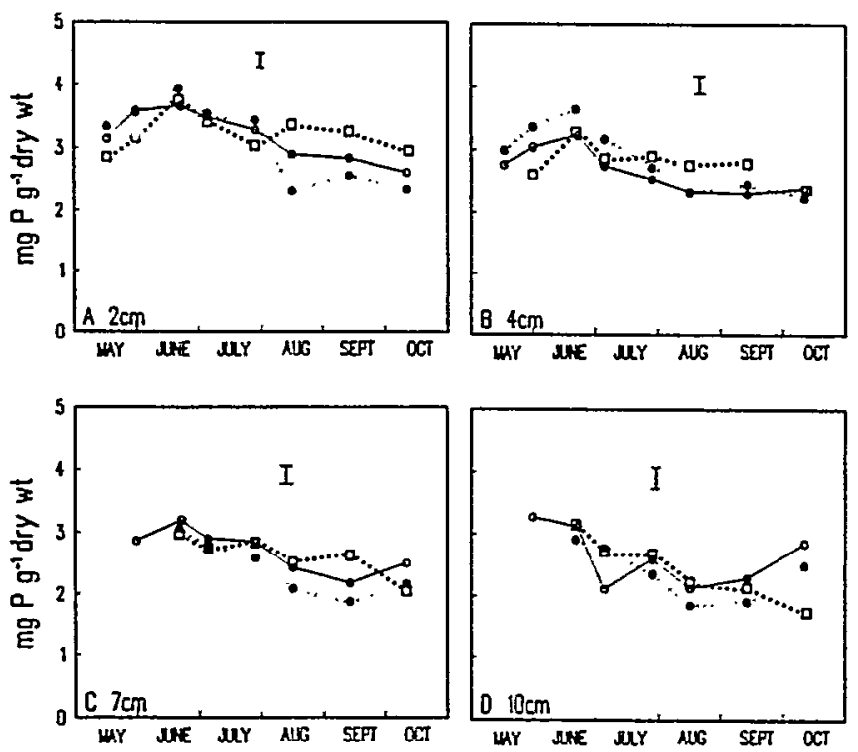

Fig. 7. Content of $P$ per unit dry weight in herbage harvested at each cut to nominal heights (A) $2 \mathrm{~cm},(B) 4 \mathrm{~cm}$, (C) $7 \mathrm{~cm}$, and (D) $10 \mathrm{~cm}$ in 1989. Insch $-0-$, Tarves ...•.... Foudland $\cdots . . .$. . All standard errors equal to or less than vertical bar $(n=4)$.
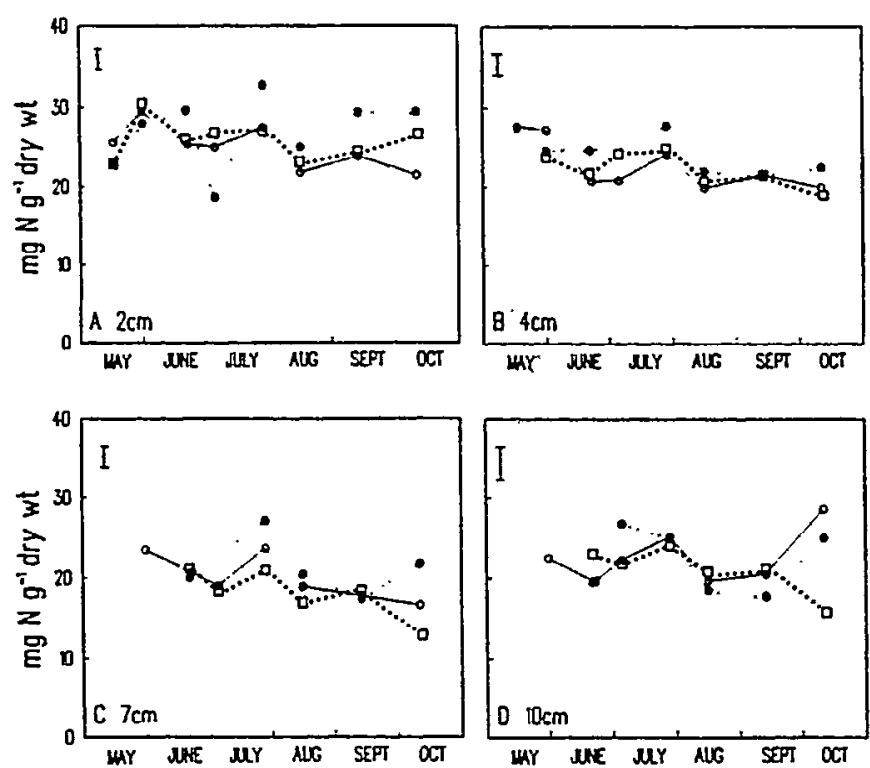

Fig. 8. Content of $\mathrm{N}$ per unit dry weight in herbage harvested at each cut to nominal heights (A) $2 \mathrm{~cm},(B) 4 \mathrm{~cm}$, (C) $7 \mathrm{~cm}$, and (D) $10 \mathrm{~cm}$ in 1989. Insch - - , Tarves $\cdots \cdot \cdots \cdots$, Foudland $\cdots \cdot \cdots \cdots$. All standard errors equal to or less than vertical bar $(n=4)$.

\section{Conclusions}

Herbage yield was considerably reduced in a drier than average growing season compared with growth in a season of average rainfall. Soil water appeared to be the limiting factor for growth, over-riding the effects of cutting treatments and nutrient availability. It must be recognized, however, that other confounding environmental factors, such as sunshine hours and soil temperature, may have had an influence on the harvest outcome.

Hill farming in Scotland is based on livestock rearing and receives a subsidy to be profitable. Below average rainfall, though never devastating, can seriously undermine farmers' livelihoods, when grazing in the late summer is poor and live weight gain reduced.

\section{Literature Cited}

Ahmed, B. 1976. Mineralization of inositol hexaphosphate in soil at varying static moisture levels. Plant and Soil 44: 253-256.

Appadurai, R. R. and W. Holmes. 1964. The influence of stage of growth, closeness of defoliation and moisture on the growth and productivity of a ryegrass - white clover sward. J. Agr. Sci. 62:327-332.

Barthram, G.T., S.A. Grant, and D.A. Elston. 1992. The effects of sward height and nitrogen fertilizer application on changes in sward composition, white clover growth and the stock carrying capacity of an upland perennial ryegrass/white clover sward grazed by sheep for four years. Grass and Forage Sci. 47: 326-341.

Bell, J.P. 1976. Neutron Probe Practice Report No 19. Institute of Hydrology, Wallingford, Oxon.

Frame, J. 1973. The yield response of a tall fescue/white clover sward to nitrogen rate and harvesting frequency. J. Brit. Grassl. Soc. 28: 139-148. 
Grant, S.A. and G.T. Barthram. 1991. The effects of contrasting cutting regimes on the components of clover and grass growth in microswards. Grass and Forage Sci. 46: 1-13.

Hendrickx, J.M.H. 1990. Determination of hydraulic soil properties, p.48-92. In: M.G. Anderson and T.P. Burt (eds.) Process studies in hillslope hydrology. John Wiley and Sons, UK.

Holliday, R. and D. Wilman. 1965. The effect of fertilizer nitrogen and frequency of defoliation on yield of grassland herbage. J. Brit. Grassl. Soc. 20: $32-40$.

Howse, K.R. 1981. A technique for using permanent neutron meter access tubes in cultivated soils. Method. Exp. Agr. 16: 265-269.

Jones, R.J.A. and J. Tinsley. 1980. Hill land studies in the Grampian Region of Scotland. 1. Effects of soil parent material, altitude and aspect on the herbage yields, composition and responses to fertilizer treatments in the Upper Don Basin. J. Soil Sci. 31: 343-370.

Käding, H. 1990. Influence of cutting height on yield, persistence and constituents of several grass species. Wirtschaftseigene Futter 36: $31-40$.

Macklon, A.E.S., L.A. Mackie-Dawson, A. Sim, C.A. Shand, and A. Lilly. 1994. Soil $P$ resources, plant growth and rooting characteristics in nutrient poor upland grassland. Plant and Soil 163: 257-266.

Mayland, H.F., K.H. Asay, and D.H. Clark. 1992. Seasonal trends in herbage yield. J. Range Manage. 45: 369-374.

McGowan, M. and J.B. Williams. 1980. The water balance of an agricultural catchment. 1. Estimation of evaporation from soil water records. J. Soil Sci. 31: 217-230.

Meteorological Office Monthly Weather Reports, Her Majesty's Stationery Office, Norwich.

Orr, S.J. and A.S. Laidlaw, 1978. The effect of nitrogen on grass and grass/clover swards under two cutting frequencies. Record Agr. Res. 26: 41-53.
Ragg, J.M. and B. Clayden. 1973. The classification of some British soils according to the comprehensive system of the United States. Soil Surv. Tech. Monogr. No. 3. Harpenden, UK.

Reid, D. 1959. Studies on the cutting management of grass-clover swards. 1. The effect of varying the closeness of cutting on the yields from an established grass-clover sward. J. Agr. Sci. 53, 299-312.

Reid, D. 1962. Studies on the cutting management of grass-clover swards. III. The effects of prolonged close and lax cutting on herbage yields and quality. J. Agr. Sci. 59: 359-368.

Reid, D. 1968. Studies on the cutting management of grass-clover swards. VI. The effects of different closeness and frequency of cutting treatments on the yicld and quality of herbage from a cocksfoot - white clover sward. J. Agr. Sci. 70: 59-64.

Robertson, J.S. 1984. A key to the common plant communities of Scotland. Soil Surv. Monogr.. MISR Aberdeen UK.

Shand, C. A., A.E.S. Macklon, A.C. Edwards, and S. Smith. 1994a. Inorganic and organic $\mathrm{P}$ in soil solutions from three upland soils. 1. Effect of soil solution extraction conditions, soil type and season. Plant and Soil 159: 255-264.

Shand, C.A., A.E.S. Macklon, A.C. Edwards, and S. Smith. 1994b. Inorganic and organic $\mathrm{P}$ in soil solutions from three upland soils. 2. Effect of defoliation and fertiliser application. Plant and Soil 160: $161-170$.

Soil Survey of Scotland. 1969. Bulletin No. 1, The Soils of Candacraig and Glenbuchat. The Macaulay Institute for Soil Research, Aberdeen, U.K.

Willms, W.D. 1991. Cutting frequency and cutting height effects on rough fescue and Parry oat grass yields. J. Range Manage. 44: 82-86.

Willms, W.D., and K.A. Beauchemin. 1991. Cutting frequency, and cutting height effects on forage quality of rough fescue and Parry oat grass. Can. J. Anim. Sci. 71: 87-96. 